\title{
Analyzing the Secondary School Students' Anxiety towards Science Course in Terms of a Number of Variables
}

\author{
Esra Ucak * \\ Pamukkale University, TURKEY
}

\author{
Serkan Say \\ Mersin University, TURKEY
}

Received: July 30, $2018 \cdot$ Revised: September 13, $2018 \cdot$ Accepted: December 4, 2018

\begin{abstract}
This study aims to investigate the anxiety levels of secondary school students towards science course depending on a number of variables. Research sample consists of 2245 students who continue their education at public schools in Denizli (west of Turkey) in the academic year of 2017-2018. "Anxiety Scale for Science Course and "Personal Information Form" are used as data collection tools in the research. SPSS 22.0 package program is used for analysis of the data. Descriptive survey model is used in research. Parametric tests including One-Way ANOVA and independent samples t-test are used for analyzing data. As a result of the research, it is found out that secondary school students' science anxiety levels significantly differ depending on the variables such as class level, the grade they received in science course, scientific books they read, the documentaries they watch, enjoying the science course and science teacher, educational level of parents, reviewing what they learn in science course and experiencing parental pressure for studying science course. However, there is found no significant difference between students' anxiety levels in terms of gender and their getting support while studying science.
\end{abstract}

Keywords: Secondary school students, science course, anxiety towards science course.

To cite this article: Ucak, E, \& Say, S. (2019). Analyzing the secondary school students' anxiety towards science course in terms of a number of variables. European Journal of Educational Research, 8(1), 63-71. doi: 10.12973/eu-jer.8.1.63

\section{Introduction}

Although science is one of the most important lessons that enhance students' cognitive development and increase their creativity, it is perceived as a difficult subject to learn by many students which hinders their success in science (Mallow, 2006; Raymond, 2003). This leads students to develop negative attitudes towards the science course and, consequently, to a reduction in success (Kagitci, 2014). Avci and Kirbaclar (2017) found a statistically significant difference between the "science anxiety levels" of students and "class level", "liking science course", "liking science teacher", "weekly period of time for studying science" and "the number of scientific magazines/books at home" variables. As seen above, affective factors are effective on students' science achievement in teaching- learning process as well as cognitive factors (Krylova, 1997; Turner and Lindsay, 2003). Affective factors include many aspects such as interest, attitude, motivation, value, belief, self-efficacy, anxiety, fear and concern. Studies conducted so far put forward that affective factors are effective on students' achievement (Dede and Yaman 2008; Duit and Treagust 2003; Tuan, Chin and Shieh, 2005).

Anxiety is one of the crucial affective factors affecting students' achievement. Anxiety has an important role for the students to develop a positive attitude toward science lessons and to increase their achievement. The results of the studies indicate that anxiety and negative attitudes become obstacles to students' participation into the teaching and learning process, and they reduce students' performance and achievement (Jegede, 2007; Osborne, Simon and Collins, 2003; Raymond, 2003; Seligman, Walker and Rossenhan, 2001; Udo, Ramsey and Mallow, 2004). Science anxiety is a reason which obstructs students' interest in science, career efforts and their participation into courses (Udo, Ramsey and Mallow, 2004). The source of science anxiety is comprised of bad experiences of students in science classes, the concerns of their teachers in elementary and secondary schools, the lack of role models, gender and racial judgement, the influence of scientists in popular media, beliefs that they'll fail to solve the science problem and in the science test (Mallow et al., 2010). Students with low level of science anxiety become more motivated in their studies and doing a career in science (Hassan, 2008). Students with low level of science anxiety and stress have higher achievement level and positive attitudes towards science (Atwater, Gardner and Wiggins, 1995).

Researchers in their studies suggested a variety of definitions about science anxiety. Mallow (1986) defined science anxiety as having disgust or fear of science concepts, scientists, science related activities. Seligman et al. (2001) defined

\footnotetext{
* Corresponding author:

Esra Ucak, Pamukkale University, Department of Science Education, Turkey.

$\bowtie$ esucak0@gmail.com
} 
science anxiety as tension which inhibits usage of scientific instruments in academic subjects or in many parts of daily life. Also, science anxiety (Oludipe and Awokoy, 2010), can be defined as a disruptive situation occurring as a result of responding to situations which threaten self-esteem including scientific studies. Some studies assert that science anxiety causes students to fear enrolling in science course and prevents them from studying in areas related to science and becoming successful in those areas (Raymond, 2003; Udo, Ramsey, Mallow, 2004). Science anxiety may be originating from school, environment or family. Science anxiety is a serious learning obstacle to science course for students (Mallow, 2010. Udo, Ramsey and Mallow (2004) draw an analogy between science anxiety and career filter; and they claim that the adolescents do not prefer areas related to science as a profession in university.

When it is investigated the effect of anxiety on instruction, it is seen that there have been conducted many studies. When reviewing studies which are conducted in Turkey, it is observed that those studies include scale development and scale adaptation. Those studies are science learning anxiety scale (Yildirim, 2015), science anxiety scale (Sagir Ulucunar, 2014) and anxiety towards science course scale (Kagitci and Kurbanoglu, 2013). In studies related to science anxiety, the variables are studied such as gender effect, anxiety among university students (Mallow, 1994; Ud o, Ramsey and Mallow, 2004; Mallow et al. 2010), anxiety towards science education (Marso and Pigge, 1998; Yuruk, 2011), anxiety towards science course (Akcoltekin and Dogan, 2013; Kagitci 2014), anxiety towards science (Avci and Kirbaslar, 2017), unsuccessful students' reasons for science anxiety (Kaya and Yildirim, 2014), relationship between risk-taking for science and science anxiety (Akca, 2017).

When related studies are reviewed, it takes attention that there is a need for more research in Turkey about anxiety towards science course. Therefore, there should be conducted qualified studies which aim to identify the factors underlying anxiety towards science course and explain its relation with different variables. In this study, variables possible to affect science anxiety of secondary school students are discussed and the question "By which variables science anxieties show differences" is tried to be answered. This study is done within this context and it aims to analyze secondary school students' science course anxiety levels in terms of several variables. Accordingly, the following questions are attempted to be answered:

* Do secondary school students' anxiety towards science course differ depending on; Gender, class level, enjoying science course and science teacher, education level of parents, grade they receive in science course, watching documentaries and reading scientific books, experiencing parental pressure for studying science, getting support while studying science, reviewing what they learn in science course?

\section{Methodology}

\section{Research Model}

This study is conducted using descriptive survey model. The most important feature of this model is that it describes an event or a situation as it is at present (Cepni, 2009). In other words, it is a research method which has a purpose of describing a situation in past or at present as how it exists (Karasar, 2008).

\section{Research Sample}

Research sample in this study consists of 2245 students at $6^{\text {th }}, 7^{\text {th }}$ and $8^{\text {th }}$ grades in different public schools in city center of Denizli during 2017-2018 education year.

\section{Data Collection}

"Personal Information Form" and "Anxiety Scale for Science Course" are used as data collection tools.

Personal Information Form: This form is developed for identifying features of participants such as gender, class level, grade of science course, education level of parents, watching documentaries and reading scientific books, enjoying science course and science teacher, reviewing what they learn in science course, getting support while studying science and experiencing parental pressure for studying science.

Anxiety Scale for Science Course: In this study, Anxiety Scale for Science Course was used as a data collection tool which was developed by Kagitci and Kurbanoglu (2013). It is one dimensional scale with 18 items. The items in the scale are scored from 1 to 5 . Thus, for each data collection tool included in the application, the total score was obtained from the sum of the item scores. The lowest score in the scale is 18, the highest is 90. The reliability of scale (Cronbach's Alpha) is found to be 0.89 and the correlation between test-retest scores appears as 0.85 .

\section{Analyzing of Data}

Statistical Packet Program SPSS 22.0 was used for analysis and evaluation of data obtained in the study. In order to identify whether answers to the scale have a normal distribution, skewness-kurtosis values, standard deviation, arithmetic mean, median and mod values were used. Before analysis of quantitative data obtained from Anxiety Scale for Science Course, it was decided which statistical method would be appropriate for each variable. Parametric or nonparametric methods can be used in analysis of quantitative data. Parametric statistical analysis methods require an 
assumption that quantitative data obtained from assessment tools should distribute normally. For identifying which statistical method would be used in analysis, descriptive analysis is done and findings are given in Table 1:

Table 1. Descriptive Statistical Results Related to Anxiety Towards Science Course

\begin{tabular}{llccllll}
\hline Category & $\mathbf{N}$ & $\bar{X}$ & SD & Mod & Median & Skewness & Kurtosis \\
\hline Attitude Towards Science Course & 2245 & 1.96 & .74 & 1.00 & 1.89 & .816 & .825 \\
\hline
\end{tabular}

According to descriptive statistical results obtained from Anxiety Scale for Science Course; arithmetic mean, median and mod values are close to each other and skewness and kurtosis values are between -1.5 and +1.5 ; therefore, those findings indicate that the data have a normal distribution (Tabachnick and Fidell, 2013). And according to the analysis based on variables, similar results are obtained and they are determined to have a normal distribution. In analysis of data which are distributed normally, parametric tests are preferred, namely Independent Samples t-test and One-Way ANOVA have been applied for identifying whether students' scores from anxiety scale differ depending on variables in this study.

\section{Findings and Interpretation}

Firstly, it has been analyzed whether secondary school students' anxiety towards science course differs depending on the variables of gender, enjoying science course and science teacher and t-test results are given in Table 2:

Table 2. T-test Results Analyzing Secondary School Students' Anxiety Scores in Terms of Gender, Linking Science Course and Science Teacher

\begin{tabular}{lccccccc}
\hline Category & Group & $\mathbf{N}$ & $\overline{\mathbf{X}}$ & SD & Df & t & $\mathbf{p}$ \\
\hline \multirow{2}{*}{ Gender } & Female & 1031 & 1,97 & 0,73 & 2243 & 0,81 & 0,419 \\
& Male & 2325 & 1,95 & 0,75 & & & \\
\hline \multirow{2}{*}{ Enjoying Science Course } & Yes & 2041 & 1,91 & 0,71 & 2239 & 10,11 & 0 \\
& No & 200 & 2,46 & 0,87 & & & \\
\hline \multirow{2}{*}{ Enjoying Science Teacher } & Yes & 2119 & 1,95 & 0,74 & 2229 & 3,44 & 0,001 \\
& No & 112 & 2,19 & 0,74 & & & \\
\hline
\end{tabular}

When Table 2 is reviewed, it is seen that there is no significant difference between students' anxiety scores in terms of gender ( $\mathrm{p}>$.05). In this regard, it is possible to claim that gender does not have an important effect on science anxiety; however, the variables of enjoying science course and science teacher have a significant effect on science anxiety $(\mathrm{p}<.05)$. It I found out that student who like science course $(\bar{X}=1.91)$ have lower anxiety scores in science compared to other who do not $(\bar{X}=2.46)$. Likewise, students who like their science teachers $(\bar{X}=1.95)$ have lower anxiety science score in science compared to other who do not $(\bar{X}=2.19)$.

Table 3 presents analysis results which identify whether secondary school students' anxiety scores differ depending on science grade in their reports, class level, reviewing what they learn in science course, watching documentaries and scientific books:

Table 3. One-Way ANOVA Results Analyzing Secondary School Students' Anxiety Scores in Terms of Science Grade in Their Reports, Class Level, Reviewing What They Learn in Science Course, Watching Documentaries and Reading Scientific Books

\begin{tabular}{|c|c|c|c|c|c|c|c|}
\hline \multirow{11}{*}{ 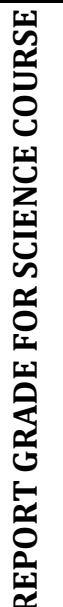 } & \multicolumn{3}{|l|}{ Variable } & \multicolumn{2}{|l|}{$\mathbf{N}$} & $\bar{x}$ & SD \\
\hline & \multicolumn{3}{|l|}{ 1.Poor } & \multicolumn{2}{|c|}{299} & 2.23 & .88 \\
\hline & \multicolumn{3}{|l|}{ 2.Weak } & \multicolumn{2}{|c|}{220} & 2.18 & .74 \\
\hline & \multicolumn{3}{|c|}{ 3.Satisfactory } & \multicolumn{2}{|c|}{354} & 2.17 & .79 \\
\hline & \multicolumn{3}{|c|}{ 4.Good } & \multicolumn{2}{|c|}{482} & 1.92 & .69 \\
\hline & \multicolumn{3}{|c|}{ 5.Excellent } & \multicolumn{2}{|c|}{890} & 1.75 & .63 \\
\hline & \multicolumn{3}{|c|}{ Total } & \multicolumn{2}{|c|}{2245} & 1.96 & .74 \\
\hline & Group & $\begin{array}{l}\text { Sum of } \\
\text { Squares }\end{array}$ & Df & Mean Squares & $\mathbf{F}$ & $\mathbf{p}$ & Difference \\
\hline & $\begin{array}{l}\text { Between } \\
\text {-Groups }\end{array}$ & 87.315 & 4 & 21.829 & 42.388 & \multirow[t]{3}{*}{.000} & $5-4,5-3,5-$ \\
\hline & $\begin{array}{l}\text { Within- } \\
\text { Groups }\end{array}$ & 1153.561 & 2240 & \multirow[t]{2}{*}{.515} & & & $\begin{array}{l}2,5-1, \\
4-3,4-2,\end{array}$ \\
\hline & Total & 1240.877 & 2244 & & & & \\
\hline
\end{tabular}


Table 3. Continued

\begin{tabular}{|c|c|c|c|c|c|c|c|}
\hline \multirow{9}{*}{ 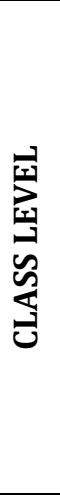 } & \multicolumn{3}{|l|}{ Variable } & \multicolumn{2}{|l|}{$\mathbf{N}$} & \multirow{2}{*}{$\frac{\bar{x}}{1.92}$} & \multirow{2}{*}{$\begin{array}{c}\text { SD } \\
.75\end{array}$} \\
\hline & $6^{\text {th }}$ grade & & & 544 & & & \\
\hline & $7^{\text {th }}$ grade & & & 859 & & 1.88 & .69 \\
\hline & $8^{\text {th }}$ grade & & & 842 & & 2.07 & .78 \\
\hline & Total & & & 2245 & & 1.96 & .74 \\
\hline & Group & $\begin{array}{l}\text { Sum of } \\
\text { Squares }\end{array}$ & Df & Mean Squares & $\mathbf{F}$ & $\mathbf{p}$ & Difference \\
\hline & $\begin{array}{l}\text { Between- } \\
\text { Groups }\end{array}$ & 17.094 & 2 & 8.547 & 15.659 & .000 & $8-6,8-7$ \\
\hline & Within-Groups & 1223.782 & 2242 & .546 & & & \\
\hline & Total & 1240.877 & 2244 & & & & \\
\hline \multirow{9}{*}{ 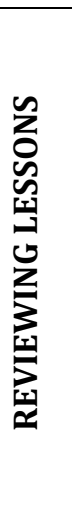 } & Variable & & & \multicolumn{2}{|l|}{$\mathbf{N}$} & $\overline{\mathrm{X}}$ & SD \\
\hline & Often (1) & & & \multicolumn{2}{|l|}{505} & 1.72 & .67 \\
\hline & Sometimes (2) & & & \multicolumn{2}{|c|}{1597} & 2.02 & .74 \\
\hline & Never (3) & & & \multicolumn{2}{|c|}{143} & 2.18 & .82 \\
\hline & Total & & & \multicolumn{2}{|c|}{2245} & 1.96 & .74 \\
\hline & Group & $\begin{array}{l}\text { Sum of } \\
\text { Squares }\end{array}$ & Df & Mean Squares & $\mathbf{F}$ & $\mathbf{p}$ & Difference \\
\hline & $\begin{array}{l}\text { Between- } \\
\text { Groups }\end{array}$ & 40.572 & 2 & 20.286 & 37.891 & .000 & 3-2, 3-1, \\
\hline & Within-Groups & 1200.305 & 2242 & .535 & & & \multirow[t]{2}{*}{$2-1$} \\
\hline & Total & 1240.877 & 2244 & & & & \\
\hline \multirow{9}{*}{ 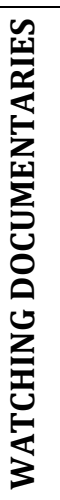 } & Variable & & & \multicolumn{2}{|l|}{$\mathbf{N}$} & $\overline{\mathrm{X}}$ & SD \\
\hline & Often (1) & & & \multicolumn{2}{|l|}{462} & 1.84 & .72 \\
\hline & Sometimes (2) & & & \multicolumn{2}{|l|}{1302} & 1.93 & .72 \\
\hline & Never (3) & & & \multicolumn{2}{|l|}{475} & 2.15 & .80 \\
\hline & Total & & & \multicolumn{2}{|l|}{2239} & 1.96 & .74 \\
\hline & Group & $\begin{array}{l}\text { Sum of } \\
\text { Squares }\end{array}$ & Df & Mean Squares & $\mathbf{F}$ & $\mathbf{P}$ & Difference \\
\hline & $\begin{array}{l}\text { Between- } \\
\text { groups }\end{array}$ & 24.849 & 2 & 12.424 & 22.902 & .000 & $3-2,3-1$ \\
\hline & Within-groups & 1213.032 & 2236 & .0543 & & & \\
\hline & Total & 1237.881 & 2238 & & & & \\
\hline & Variable & & & $\mathbf{N}$ & & $\bar{X}$ & SD \\
\hline ำ & Often (1) & & & 429 & & 1.81 & .74 \\
\hline ๑ొ & Sometimes (2) & & & 1338 & & 1.97 & .73 \\
\hline ن & Never (3) & & & 478 & & 2.07 & .76 \\
\hline 绿 & Total & & & 2245 & & 1.96 & .74 \\
\hline 놀 & Group & $\begin{array}{l}\text { Sum of } \\
\text { Squares }\end{array}$ & Df & Mean Squares & $\mathbf{F}$ & $\mathbf{P}$ & Difference \\
\hline 崩 & $\begin{array}{l}\text { Between- } \\
\text { Groups }\end{array}$ & 15.336 & 2 & 7.668 & 14.028 & .000 & $3-2,3-1$ \\
\hline$\sum_{4=1}^{9}$ & Within-Groups & 1225.541 & 2242 & .547 & & & $2-1$ \\
\hline & Total & 1240.877 & 2244 & & & & \\
\hline
\end{tabular}

According to Table 3, it is found out that students' anxiety scores related to science course differentiates significantly depending on their report grade of science course. Report grades are classified as 1 (poor), 2 (weak), 3 (satisfactory), 4 (good) and 5 (excellent). When students' science anxiety is analyzed within these categories, it comes out that students with grade 5 (excellent) have lower anxiety scores $(\bar{X}=1.75)$ compared to those with report grade 4 ( $\bar{x}=1.92), 3$ $(\bar{X}=2.17), 2(\bar{X}=2.18)$ and $1(\bar{X}=2.23)$. In other words, students with higher report grades have lower science anxiety. When results of Tukey HSD analysis are reviewed, it is seen that students' anxiety scores who get 5 and 4 grades in their science course differ compared to students with report grade of 3,2 and 1.

According to Table 3, secondary school students' science anxiety levels differ depending on their class level ( $F=15,65$; $\mathrm{p}<0,05)$. When results of Tukey HSD analysis are reviewed, it comes out that $8^{\text {th }}$ graders anxiety scores differ compared 
to $6^{\text {th }}$ and $7^{\text {th }}$ graders' science anxiety scores. When students' anxiety scores are reviewed in Table, it is determined that the mean of science anxiety scores for $8^{\text {th }}$ graders is $(\bar{X}=2.07), 7^{\text {th }}$ graders is $(\bar{X}=1.88)$ and $6^{\text {th }}$ graders $(\bar{X}=1.92)$. Accordingly, the highest science anxiety scores belong to $8^{\text {th }}$ graders while the lowest scores belong to $7^{\text {th }}$ graders.

According to Table 3, it is seen that students' science anxiety scores differ significantly depending on whether they review what they learn in science course $(\mathrm{F}=37,89 ; \mathrm{p}<0,05)$. Reviews of lessons have been classified into "often", "sometimes", "never" and students' science anxiety is analyzed based on these categories. It is found out that students who make reviews of lessons often $(\bar{X}=1.72)$ have lower science anxiety compared to students who do sometimes $(\bar{X}=2.02)$ and those who do not review what they learn in science course $(\bar{X}=2.18)$.

According to Table 3, reading scientific books and watching documentaries affect students' science anxiety in a positive way at a significant degree $(\mathrm{p}<0,05)$. Reading books and watching documentaries have been classified into "often", "sometimes" and "never" and science anxiety of students is analyzed based on those categories. It is found out students who read scientific books often have lower science anxiety $(\bar{X}=1.81)$ compared to students who do sometimes ( $3=1.97)$ and those who do never read scientific books ( $\bar{X}=2.07)$. Likewise, students who watch documentaries often have lower science anxiety $(\bar{X}=1.84)$ compared to students who do sometimes $(\bar{X}=1.93)$ and those who never watch documentaries.

Table 4 presents analysis results which identify whether secondary school students' anxiety scores differ depending on their parents' educational level, getting support while studying science and experiencing parental pressure for studying science:

Table 4. One-Way ANOVA Results Analyzing Secondary School Students' Anxiety Scores in Terms of Their Parents' Educational Level, Getting Support while Studying Science and Experiencing Parental Pressure for Studying Science

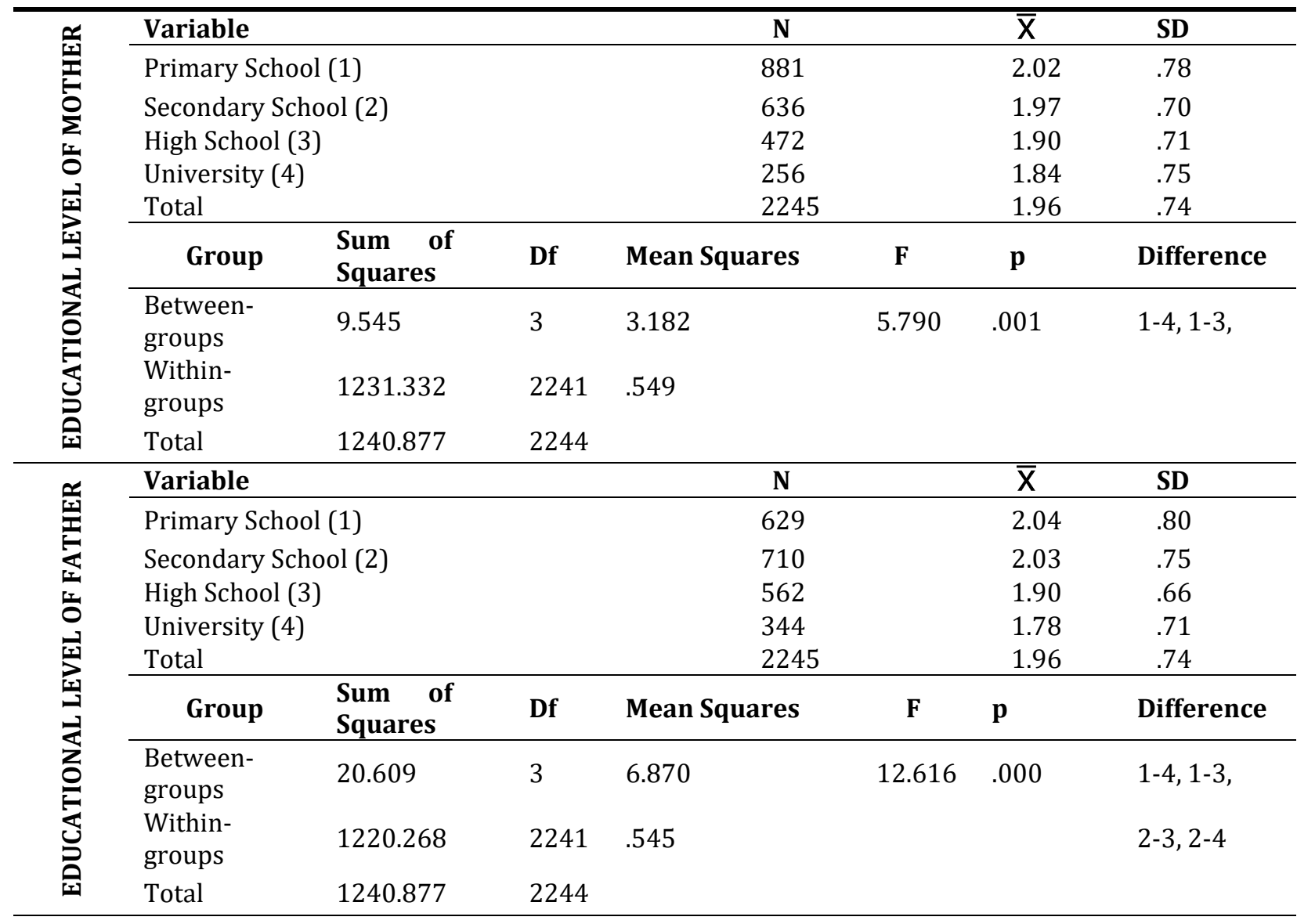


Table 4. Continued

\begin{tabular}{|c|c|c|c|c|c|c|c|}
\hline \multirow{10}{*}{ 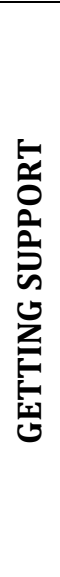 } & \multicolumn{3}{|l|}{ Variable } & \multicolumn{2}{|l|}{$\mathbf{N}$} & $\overline{\mathrm{X}}$ & SD \\
\hline & \multicolumn{3}{|l|}{ Mother (1) } & \multicolumn{2}{|l|}{442} & 1.95 & .76 \\
\hline & \multicolumn{3}{|c|}{ Father (2) } & \multicolumn{2}{|l|}{434} & 1.90 & .68 \\
\hline & \multicolumn{3}{|c|}{ Elder Sister /Brother (3) } & \multicolumn{2}{|l|}{531} & 1.96 & .72 \\
\hline & \multicolumn{3}{|c|}{ None (4) } & \multicolumn{2}{|l|}{838} & 1.99 & .78 \\
\hline & Total & & & \multicolumn{2}{|l|}{2245} & 1.96 & .74 \\
\hline & Group & $\begin{array}{l}\text { Sum of } \\
\text { Squares }\end{array}$ & Df & Mean Squares & $\mathbf{F}$ & $\mathbf{p}$ & Difference \\
\hline & $\begin{array}{l}\text { Between- } \\
\text { groups }\end{array}$ & 2.417 & 3 & .806 & 1.458 & \multirow[t]{2}{*}{.224} & \multirow[t]{2}{*}{-} \\
\hline & $\begin{array}{l}\text { Within- } \\
\text { groups }\end{array}$ & 1238.459 & 2241 & .553 & & & \\
\hline & Total & 1240.877 & 2244 & & & & \\
\hline \multirow{9}{*}{ 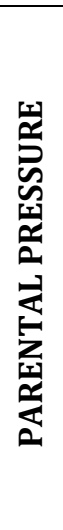 } & \multicolumn{2}{|l|}{ Variable } & & \multicolumn{2}{|l|}{$\mathbf{N}$} & $\bar{X}$ & SD \\
\hline & \multicolumn{2}{|l|}{ Often (1) } & & \multicolumn{2}{|l|}{393} & 2.07 & .68 \\
\hline & \multicolumn{2}{|c|}{ Sometimes (2) } & & \multicolumn{2}{|l|}{883} & 2.06 & .75 \\
\hline & \multicolumn{2}{|c|}{ Never (3) } & & \multicolumn{2}{|l|}{696} & 1.82 & .74 \\
\hline & Total & & & \multicolumn{2}{|l|}{2245} & 1.96 & .74 \\
\hline & Group & $\begin{array}{l}\text { Sum of } \\
\text { Squares }\end{array}$ & Df & Mean Squares & $\mathbf{F}$ & $\mathbf{p}$ & Difference \\
\hline & $\begin{array}{l}\text { Between- } \\
\text { groups }\end{array}$ & 31.727 & 2 & 15.864 & 29.414 & .000 & $1-3,2-3$ \\
\hline & $\begin{array}{l}\text { Within- } \\
\text { groups }\end{array}$ & 1209.150 & 2242 & .539 & & & \\
\hline & Total & 1240.877 & 2244 & & & & \\
\hline
\end{tabular}

According to Table 4, it reveals that students' anxiety towards science course differs depending on their parents' educational level $(\mathrm{p}<0.05)$. When students' anxiety levels are analyzed in terms of their parents' educational level, it is observed that students whose mothers are university graduates $(\bar{X}=1.84)$ have lower anxiety scores compared to students whose mothers are primary school graduates $(\bar{X}=2.02)$, secondary school graduates $(\bar{X}=1.97)$ and high school graduates $(\bar{X}=1.90)$. Likewise, students' whose fathers are university graduates $(\bar{X}=1.78)$ have lower anxiety scores compared to students whose fathers are primary school graduates $(\bar{X}=2.04)$, secondary school graduates $(\bar{X}=2.03)$ and high school graduates $(\overline{\mathrm{X}}=1.90)$.

According to Table 4, it is seen that students' anxiety levels in science courses do not differ significantly depending on their getting support while studying science $(p>0,05)$.

According to Table 4, it is seen that students' anxiety levels in science courses differ significantly depending on whether they experience parental pressure for studying science $(\mathrm{p}<0,05)$. Parents' pressure is classified into three categories as "often", "sometimes", "never" and when students' anxiety towards science course is analyzed, it is found out that students who experience pressure "often" have higher anxiety levels ( $\bar{X}=2.07)$ compared to students experiencing pressure "sometimes" ( $\overline{\mathrm{X}}=2.06)$ and never $(\overline{\mathrm{X}}=1.82)$.

\section{Conclusion}

This research aims to identify whether secondary school students' anxiety towards science course significantly differ depending on several variables. As a result of analysis in this research, it is found out that students' anxiety scores towards science course do not significantly differ depending on variable of gender. There are a number of studies which indicate that there is not a significant difference between anxiety scores of students in terms of gender (Kagitci, 2014; Akman, Izci, Bagce and Akilli, 2007; Aydin et al. 2009; Dede and Dursun, 2008; Yenilmez and Ozbey, 2006; Avci and Kirbaslar, 2017).

On the other hand, students' enjoying science course and science teacher has a significant effect on students' anxiety in science courses. It is observed that students who like their science courses get lower anxiety scores compared to students who do not. Additionally, students who like their science teachers get lower anxiety scores compared to students who do not. Parallel to the findings of the study, Gomleksiz and Yuksel (2003) determined in their studies that primary school students felt anxiety towards science course due to a lack of communication with the teacher. Kaya and Yildirim (2014) carried out a study for examining the sources of science anxiety of unsuccessful students and they put forth that one of the reasons for science anxiety might be the attitude of the science teachers. Avci and Kirbaslar (2017) 
in their studies conclude that students who read scientific books regularly have lower science anxiety. Students' lack of belief in their ability to achieve this course lies at the bottom of their anxiety towards science courses. In this regard, it is teachers' responsibilities to encourage students and make them believe in their capabilities of achieving science. Therefore, teachers should do their best and attempt to make the course amusing and enjoyable, keep students' motivation high and help them like the course. Teachers should endear not only courses but also themselves to the students.

Analyzing whether the students' anxiety scores towards science courses show a significant difference according to the science grade in their report, it is observed that there is a significant difference between the science course anxiety scores and the science grade students get in their reports. Students with higher grades of science in their reports are less anxious about science courses. In other words, as students' achievements in science course increase, their anxiety scores decrease. Yenilmez and Ozbey (2006) found that, as students' mathematical achievements increased, their anxiety scores decreased. They explain the reason for this situation as in the following: It is natural that the students who fail in mathematics courses have high anxiety levels because they tend to generalize the failure situation in the course and have anxiety believing that they will experience the same failure situation while learning new concepts. However, since they do not find themselves capable enough, every question to be asked or every new concept to be learned can be a frustrating situation for students. In other words, students' success in courses increases their confidence as a learner and they possibly do not regard science as an impassable obstacle and do not experience anxiety. High success -along with enjoying science course and enjoying studying science- may also be an indication for successful students to think that there is no reason to worry.

As a result of analysis which is done to identify whether the students' anxiety in science courses differ significantly depending on their class level, it appears there is a meaningful difference between science course anxiety scores and variable of class level. According to this result, it is seen that the class level variable has an important effect on anxiety towards science course. It is found out that $8^{\text {th }}$ graders have the highest anxiety points in science courses. Similar findings were obtained by different researchers. (Genc, 2013; Hassan, 2008; Ulucinar and Sagir, 2012; Sirmaci, 2007; Avci and Kirbaslar, 2017). When current examination system is taken into consideration, $8^{\text {th }}$ graders will take a national exam of LGS, and this might be increasing their anxiety levels towards science course.

According to research findings, there is found a statistically significant difference among groups depending on students' reading scientific books and watching documentaries. This shows that students' reading appropriate scientific books and watching documentaries -in order to learn scientific and technological advances, the scientific knowledge needed in daily life and the subjects they are curious about- differentiate the level of anxiety towards science. According to the research findings, it is also found out that the students' anxiety scores towards science courses differ significantly depending on whether they review what they learn in science courses. The fact that the difference is in favor of those who make lesson reviews at home suggests that students who do not review their lessons at home have higher anxiety scores towards science courses. Similarly, in study of Hunter and Kirbaslar (2017), it is concluded that students who read books with scientific content and make regular weekly reviews of lessons at home have lower anxiety levels in science courses.

Secondary school students' anxiety levels in the science courses have been compared according to the educational level of the parents. In the analysis of the data, it is determined that as the education level of the parents increases, students' anxiety scores decrease. According to the researchers conducted, there are attitude differences between primary school graduate parents and high school graduate parents. Gumus (1997) found that there was a significant difference between parents' educational status and children's social anxiety levels, indicating that students whose parents are college graduates have lower anxiety scores. This situation might stem from the fact that educated parents raise child taking into consideration of their child's developmental characteristics. This is because there is a significant relationship between parents' pressure for studying and anxiety towards science courses. Students who feel parental pressure for studying science are also found to have higher anxiety scores for science courses. However, there is found no significant difference related to students' anxiety in science courses depending on the support of science teachers or their siblings. Therefore, this conclusion cannot be attributed to the fact that educated parents can help their children more about science and they are more knowledgeable in this regard. It is only possible to claim that parents can reduce the students' anxiety towards science lessons only with their conscious parental behaviors. In a study by Kaya and Yildirim (2014), they conducted semi-structured interviews with six $9^{\text {th }}$ grade students who failed in chemistry course to investigate the sources of science anxiety. As a result of their research, it is manifested that students' science anxiety stems from boring activities in class, fear of testing, their perceptions of chemistry, teachers' attitudes and their families' attitudes.

At this point, parents have a responsibility not to put pressure on studying science; but to stimulate students' interest and their curiosity for science course, to help them like their science courses and teachers and be successful. Therefore, parents may contribute to reduce the anxiety in science classes. In particular, it is regarded that teachers are important in reducing the anxiety in science classes by endearing themselves and their lessons to students. It is found out that students who are interested in science courses and science teachers have lower anxiety towards science courses. Teachers also have certain responsibilities from this perspective of view. Students should be supported by positive 
parental attitude at home and then by school science teachers and school guidance service when students experience anxiety towards science courses. It is suggested that science teachers should support their students to read scientific books, magazines and watch documentaries. Also, students should be encouraged to review what they learn in science course when they arrive at home after school. For example, science diaries can be kept to repeat daily learnings. These research findings are limited with city center of Denizli. It is recommended for future studies to be conducted in different cities with higher number of students and different variables.

\section{References}

Akca, B. (2017). Ortaokul ogrencilerinin fene yonelik zihinsel risk alma davranislari ile fen kaygilari arasindaki iliskinin belirlenmesi [Determining the relationship between secondary school students' mental risk taking behaviour and science anxiety](Unpublished master's thesis). Adnan Menderes University, Aydın, Turkey.

Akcoltekin, A., \& Dogan, S. (2013). Ilkogretim 6. sinif ogrencilerinin fen bilgisi dersine iliskin kaygilarinin farkli degiskenler acisindan incelenmesi [Examining the 6th grade secondary school students' anxiety towards science in terms of different variables]. The Journal of Academic Social Science Studies, 6(2), 13-29.

Akman, B., Izci, U., Bagce, H., \& Akilli, H., I. (2007). Ilkogretim ogrencilerinin fene karsi tutumlarinin sinav kaygi duzeylerine etkisi [The effect of Secondary School Students' attitudes towards science on the exam anxiety level of the students]. Education and Science, 32(146), 3-11.

Atwater, M. M., Gardner, C. M., \& Wiggins, J. (1995). A study of urban middle school students with high and low attitudes toward science. Journal of Research in Science Teaching, 32, 665-77.

Avci, F., \& Kirbaslar, F.G. (2017). Determination of factors affecting the science anxiety levels of secondary school students. Necatibey Faculty of Education Electronic Journal of Science and Mathematics Education, 11(1), 401-417.

Aydin, E., Delice, A., Dilmac, B., \& Ertekin, E. (2009). The influence of gender, grade and institution on primary school mathematics student teacher's anxiety levels. Elementary Education Online, 8(1), 231-242.

Can, A. (2016). SPSS ile Bilimsel Arastirma Surecinde Nicel Veri Analizi (4. Baski) [Quantitative data analysis in the process of scientific research with SPSS (4 ${ }^{\text {th }}$ Edition)]. Ankara: Pegem.

Cepni, S. (2009). Arastirma ve Proje Calismalarina Giris [Introduction to Research and Project Work ]. Trabzon: Celepler Printing .

Dede, Y., \& Dursun, S. (2008). Ilkogretim ikinci kademe ogrencilerinin matematik kaygi puanlarinin incelenmesi [Examining Secondary School Students' Maths Anxiety scores]. Journal of Uludag University Faculty of Education, $X X I(2), 295-312$.

Dede, Y., \& Yaman, S. (2008). A questionnaire for motivation toward science learning: a validity and reliability study. Necatibey Faculty of Education Electronic Journal of Science and Mathematics Education, 2, (1), 19-37

Duit, R., \& Treagust, D. F. (2003). Conceptual change: a powerful framework for improving science teaching and learning. International Journal of Science Education, 25(6), 671-688.

Genc, M. (2013). Ilkogretim Ogrencilerinin Sinif ve Cinsiyete Gore Sinav Kaygi puanlarinin Belirlenmesi [Determining the Exam Anxiety Scores of Elementary School Students In terms of Grades and Genders ]. Journal of Social Sciences, 11(1), 85-95

Gomleksiz, M. N., \& Yuksel Y. (2003). Ilkogretim 4. ve 5. Sinif ogrencilerinin fen bilgisi dersine iliskin kaygilari [5th and 6th Grade Elementary School Students' Anxiety Towards Science]. Researches of Eastern Anatolian Region, 1(3), 71-81.

Gumus, A. (1997). Universite ogrencilerinin sosyal kaygi puanlarinin cesitli degiskenlere gore incelenmesi, [Examining the Social Anxiety Scores of University Students in terms of different variables] (Unpublished Master's thesis). Gazi University, Ankara, Turkey.

Hassan, G. (2008). Attitudes toward science among Australian tertiary and secondary school students. Research in Science \& Technological Education, 26(2), 129-147.

Jegede, S. A. (2007). Students' anxiety towards the learning of chemistry in some Nigerian secondary schools. Educational Research and Review, 2(7), 193-197.

Kagitci, B., \& Kurbanoglu, N. I. (2013). Fen ve teknoloji dersine yonelik kaygi olceginin gelistirilmesi: guvenirlik ve gecerlik calismasi [Developing an anxiety scale for Science and Technology; A study of efficiency and reliability]. Journal of Turkish Science Education, 10(3), 95-107.

Kagitci, B. (2014). Fen dersine yonelik kaygi olcegi gelistirilmesi ve ortaokul ogrencilerinin fen dersi kaygi ile tutum puanlarinin cesitli degiskenlere gore incelenmesi [Developing an anxiety scale for science and examining secondary 
school students' attitudes and anxiety scores towards science in terms of different variables] [Unpublished master's thesis). Sakarya University, Sakarya, Turkey.

Karasar, N. (2008). Bilimsel Arastirma Yontemi (19. Baski). [Scientific method of research (19th Edition)] Ankara: Nobel.

Kaya, E., \& Yildirim, A. (2014). Science Anxiety among Failing Students. Elementary Education Online, 13(2), 518-525.

Krylova, I. (1997). Investigation of causes of differences in student performance on the topics of stereochemistry and reaction mechanisms in an undergraduate organic chemistry course (Unpublished Doctorate Thesis). Catholic University of America, Washington, D. C. , USA.

Mallow, J. V., \& Greenburg, S. L. (1983). Science anxiety and science leaming. The Physics Teacher, 21(2), 95-99.

Mallow, J.V. (1994). Gender-related science anxiety: A first binational study. Journal of Science Education and Technology, 3(4), 227-238.

Mallow, J.V. (2006). Science anxiety: Research and action. Handbook of College Science Teaching. In J.J Mintzes and W.H Leonard, (Eds.), NSTA Press. Virginia, USA

Mallow J. V., Kastrup H., Bryant, F. B., Hislop, N., Shefner, R., \& Udo, M. (2010). Science anxiety, science attitudes, and gender: Interviews from a binational study. Journal of Science Educational Technology, 19(4), 356-369.

Mallow, J. (1986). Science Anxiety. Clearwater, FL: H\&H Publication.

Marso, R. N., \& Pigge, F. L. (1998). A longitudinal study of relationships between attitudes toward teaching, anxiety about teaching, self-perceived effectiveness, and attrition from teaching. Paper presented at the Annual Meeting of the Association of Teacher Educators, Dallas, TX.

Oludipe, D., \& Awokoy J. O. (2010). Effect of cooperative learning teaching strategy on the reduction of students' anxiety for learning chemistry. Journal of Turkish Science Education, 7(1), 30-36.

Osborne, J., Simon, S., \& Collins, S. (2003). Attitudes towards science: a review of the literature and its implications. International Journal of Science Education, 25(9), 1049-1079.

Raymond R. W. (2003). The development of an instrument to assess chemistry perceptions. Unpublished Dissertation, Graduate Faculty of Texas Tech University

Sagir-Ulucinar, S. (2014). Ilkogretim ogrencilerine yonelik fen kaygi olcegi. [Science anxiety scale for primary school students]. Journal of Buca Education Faculty. 37(2014), 1-20.

Seligman Walkman, M. E. P. \& Walker, E. F., \& Rossenhan, D. L. (2001). Abnormal Psychology (4th edition). NY: W. W. Norton \& Company, Inc.

Sirmaci, N. (2007). Universite ogrencilerinin matematige karsi kaygi ve tutumlarinin incelenmesi: Erzurum ornegi [Examiming university students' anxiety and attitudes towards Maths: Sample of Erzurum]. Education and Science, 32(145), 53-70.

Tabachnick, B. G., \& Fidell, L. S. (2013). Using multivariate statistics (6th Edition). Boston: Pearson.

Turner, R. C., \& Lindsay, H. A. (2003). Gender differences in cognitive and noncognitive factors related to achievement in organic chemistry. Journal of Chemical Education, 80(5), 563-568.

Tuan, H. L., Chin, C. C., \& Sheh, S. H. (2005). The development of a questionnaire to measure students' motivation towards science learning. International Journal of Science Education, 27(6), 634-659.

Udo, M. K., Ramsey, G. P., \& Mallow, J. V. (2004). Science anxiety and gender in students taking general education science courses. Journal of Science Education and Technology, 13(4),435-446.

Ulucinar Sagir, S. (2012). The primary school students' attitude and anxiety towards science. Journal of Baltic Science Education, 11(2), 127-140.

Yenilmez, K., \& Ozbey, N. (2006). Ozel okul ve devlet okulu ogrencilerinin matematik kaygi duzeyleri uzerine bir arastirma. [A research on the maths anxiety level of public school students and private school students] Journal of Education Faculty, 19(2), 431-448.

Yildirim, B. (2015). Fen bilimleri ogrenme kaygi olcegi: Gecerlilik ve guvenirlilik calismasi [Science learning anxiety scale: Validation study]. Journal of Social Science of Mus Alparslan University, 3(1), 33-43.

Yuruk, N. (2011). The predictors of preservice elementary teachers' anxiety about teaching science. Journal of Baltic Science Education, 10(1), 17-26. 